\title{
LAPORAN KEUANGAN BERBASIS STANDAR AKUNTANSI KEUANGAN PADA BADAN \\ LAYANAN UMUM DAERAH DI LINGKUNGAN DINAS KOPERASI DAN UMKM \\ PEMERINTAH PROPINSI JAWA TIMUR
}

\author{
Yona Octiani Lestari \\ Fakultas Ekonomi,Universitas Islam Negeri Maulana Malik Ibrahim Malang \\ Jl. Gajayana 50 Malang Telp. 0341-551354 Faks. 0341-572533 \\ No.Telp:08164292906, Email: yonaoctiani@yahoo.com
}

\begin{abstract}
Indonesian government has established a microcredit plan for Union or Koperasi and UMKM, which goes by abbreviation: KUMKM. This microcredit plan requires benefited Koperasi and UMKM to give periodical financial report based on Indonesian general financial accounting standard as a proof of progression. This seems to be major factor of current microcredit plan. BPS added value survey in 2008 showed that 98\% KUMKM in Indonesia seems to independently support themselves. The report indicates that KUMKM could face structural difficulties in obtaining capital assistance and other financial aids due to their incapability of making appropriate financial report. In order to further assist potential KUMKM, Regional Public Service Agencies (BLUD) should implement detailed financial report system based on general financial accounting standards. Furthermore, recognitions and measurements all accounts must comply with rules governing the Financial Accounting Standards Board
\end{abstract}

\section{PENDAHULUAN}

\section{Latar Belakang}

Beberapa penelitian tentang Usaha Mikro Kecil dan Menengah (UMKM) yang pernah dilakukan oleh berbagai lembaga dan instansi baik yang bersifat regional maupun nasional mengindikasikan adanya permasalahan pendanaan dalam setiap permasalahan utama yang dihadapi. Bahkan dari penelitian terakhir yang dilakukan oleh International Finance Corporation (IFC) dan World Bank tentang Memulai Usaha (Doing Business) Tahun 2008 yang menempatkan Indonesia pada posisi 129 dari 181 negara yang diteliti, dimana variabel Kemudahan Mendapat Kredit (Getting Credit) untuk usaha hanya mendapatkan nilai Indeks 3 dari nilai tertinggi 10.

Penelitian ini tentunya mendukung penelitian BPS tentang Survei Nilai Tambah UMKM Tahun 2008 yang menyebutkan 96,18\% modal usaha yang digunakan adalah milik sendiri. Hal ini mengindikasikan kesulitan yang sangat besar dalam mengakses akses keuangan resmi khususnya perbankan dan lembaga keuangan lainnya. Jumlah Koperasi 
Usaha Mikro Kecil dan Menengah (KUMKM) yang telah mendapat perkuatan modal dari perbankan (bankable) mencapai 2,96 juta dengan pertumbuhan kredit 24,82 \%. Dengan demikian berarti masih terdapat 1,24 juta KUMKM yang belum mampu mengakses permodalan dari pihak perbankan (tidak bankable) pada umumnya pada level Usaha Mikro dan Kecil. (sumber data : BI Cabang Surabaya).

Jumlah pelaku ekonomi KUMKM terbesar dan tersebar diseluruh pelosok wilayah perkotaan dan pedesaan. Lapangan usaha KUMKM meliputi beberapa sektor, yaitu sektor : (1) Pertanian, (2) Pertambangan dan penggalian, (3) Industri pengolahan, (4) Listrik, gas dan air bersih, (5) Konstruksi, (6) Perdagangan, hotel dan restoran, (7) Pengangkutan dan komunikasi, (8) Keuangan, persewaan, dan jasa perusahaan, serta (9) Jasa-jasa

\section{Usaha Mikro, Kecil dan Menengah}

\begin{tabular}{|c|c|c|c|c|}
\hline No & URAIAN & SATUAN & $\begin{array}{c}\text { RENSTRA DINAS } \\
\text { KOPERASI DAN PKM } \\
(2005.2008)\end{array}$ & BPS (2006) \\
\hline 1. & Omzet < Rp. 50 juta & PK & 2.269 .668 & 3583.699 \\
\hline 2 & Omzet R.p. 50 - Rp. 500 juta & PK & 17.560 & 597.737 \\
\hline 3 & Omzet Rp. 500 - Ro. 2 milyer & PK & 1.856 & $24: 28$ \\
\hline \multirow[t]{2}{*}{4} & Hengusatia Merrergyah & PM & 440 & 0.998 \\
\hline & JUMLAH & PKM & 2.320 .000 & 4.211 .562 \\
\hline
\end{tabular}

Secara garis besar, program dana bergulir merupakan sebuah program yang diluncurkan pemerintah untuk memberikan fasilitas kemudahan dana bagi UMKM dalam permodalan maupun pembiayaan usaha. Pada dasarnya, dana bergulir memberikan fasiltias dana dengan bunga rendah bahkan tanpa bunga, untuk kemudian dana tersebut diberikan kepada UMKM lain secara berkelanjutan. Keberlanjutan dari program ini adalah dapat dirumuskannya desain yang tepat dengan tidak meninggalkan tata kelola keuangan pemerintahan yang benar.

Upaya untuk memperkecil permasalahan tersebut telah dilakukan dan akan terus dilanjutkan secara bertahap, salah satu diantaranya meningkatkan kapasitas usaha melalui perkuatan modal. Pemberdayaan KUMKM, sebagaimana dijelaskan dalam Peraturan Daerah Propinsi Jawa Timur Nomor 4 tahun 2007 tentang Pemberdayaan Koperasi, Usaha Mikro Kecil dan Menengah, khususnya pasal 9 berbunyi : Pemberdayaan koperasi usaha kecil dan Menengah dalam bentuk : (a) pendidikan dan pelatihan, (b) perkuatan permodalan, (c) pembinaan manajemen, (d) bimbingan teknis, (e) pemasaran produk dan (f) fasilitasi hak atas kekayaan intelektual (HAKI). Berdasarkan Perda tersebut pemberdayaan KUMKM dalam bentuk perkuatan permodalan telah dilaksanakan oleh Dinas Koperasi PK dan M Propinsi Jawa Timur, namun belum optimal sesuai sasaran dan pengendalian penggunaan dana oleh penerima dana bergulir belum dilakukan secara memadai. Dengan demikian pengelolaan keuangan dana bergulir tersebut seharusnya dikelola secara akuntabel sesuai dengan peraturan keuangan negara. 
Peraturan Pemerintah RI No.23 Tahun 2005 tentang Pengelolaan Keuangan Badan Layanan Umum (BLU), Peraturan Menteri Dalam Negeri 61 Tahun 2007 tentang Pedoman Teknis Pengelolaan Keuangan Badan Layanan Umum Daerah dan Peraturan Gubernur Jawa Timur Nomor 29 tentang Penerapan Pola Pengelolaan BLUD Provinsi Jawa Timur sebagai salah satu pedoman yang mendasari perlunya dibentuk BLUD Pengelolaan Dana Bergulir bagi KUMKM Unit Kerja Dinas Koperasi, Pengusaha Kecil dan Menengah Propinsi Jawa Timur, diharapkan secara internal pemerintah daerah dapat meningkatkan akuntabilitas pengelolaan keuangan dan profesionalisme layanan pendanaan bergulir kepada KUMKM guna mewujudkan tata kelola pemerintahan yang baik (good governence) dan secara eksternal dapat meningkatkan kapasitas dan produktifitas usaha KUMKM. Dengan demikan KUMKM akan dapat mengembangkan skala usahanya yang dapat menyerap tenaga kerja mengurangi pengangguran dan kemiskinan di Jawa Timur. Pengelolaan keuangan dana bergulir perlu dilaksanakan sesuai tatakelola yang baik (good governance) yang mengedepankan asas-asas prudential dan penyaluran dana bergulir tersebut perlu dilakukan pembenahan secara memadai sesuai dengan peraturan keuangan negara sehingga mengurangi potensi merugikan keuangan APBD Propinsi Jawa Timur.

Dalam rangka perwujudan tersebut maka BLUD perlu menerapkan pola pola pelaporan keuangan berdasarkan dengan Standar Akuntansi pemerintahan yang berlaku umum, pengakuan dan pengukuran atas semua akun harus sesuai dengan tata aturan dalam Standar Akuntansi Pemerintahan.

\section{Masalah Penelitian}

Berdasarkan latar belakang penelitian di atas, dirumuskan permasalahan sebagai berikut:

1. Bagaimanakah pengakuan dan penilaian transaksi yang sesuai dengan Standar Akuntansi pemerintahan yang berlaku di Indonesia

2. Bagaimanakah desain pelaporan yang sesuai dengan Standar Akuntansi pemerintahan

\section{Tujuan Penelitian}

Dana bergulir telah dilaksanakan sejak beberapa tahun yang lalu yaitu periode tahun 2001 s.d sekarang, namun dalam pelaksanaannya perlu dilakukan beberapa pembenahan dalam tata kelola, pemberdayaan dana bergulir, standar pelayanan minimum atas dana bergulir dan desain pelaporan dana bergulir. Dalam pembuatan desain pelaporan ini perlu disesuaikan dengan standar akuntansi pemerintahan yang berlaku umum. Tujuan pembuatan desain pelaporan keuangan dana bergulir ini adalah untuk :

1. Untuk menghindari ketidaksesuaian antara pelaporan akuntansinya dengan standar akuntansi pemerintahan yang berlaku umum 
2. Sebagai pedoman penetapan tata aturan pelaporan yang sesuai dengan standar akuntansi pemerintahan yang berlaku umum di wilayah Dinas KUMKM propinsi Jawa Timur.

\section{Manfaat Penelitian}

Manfaat dari pembuatan studi empiris ini diharapkan akan memberikan manfaat sebagai berikut:

1. Sebagai bahan pengambilan kebijakan bagi Pemerintah Provinsi Jawa Timur khususnya Bappeprov, Biro Ekonomi, Dinas Koperasi dan UMKM, dan Dinas terkait lainnya dalam pembuatan laporan dana bergulir bagi Koperasi dan UMKM.

2. Sebagai informasi bagi stakeholder dan public yang terkait Koperasi dan UMKM dalam memperoleh informasi keuangan, dan landasan dalam pengambilan kebijakan.

Sebagai bahan naskah akademis yang bertujuan membuat landasan bagi pengambilan kebijakan tentang pengelolaan dana bergulir.

\section{TINJAUAN PUSTAKA}

\section{Ruang lingkup Standar Akuntansi Pemerintahan}

Tujuan standar ini adalah untuk menggambarkan penyajian laporan keuangan untuk tujuan umum (general purpose financial statements) dalam rangka meningkatkan keterbandingan laporan keuangan baik terhadap anggaran, antar periode, maupun antar entitas. Laporan keuangan untuk tujuan umum adalah laporan keuangan yang ditujukan untuk memenuhi kebutuhan bersama sebagian besar pengguna laporan. Untuk mencapai tujuan tersebut, standar ini menetapkan seluruh pertimbangan dalam rangka penyajian laporan keuangan, pedoman struktur laporan keuangan, dan persyaratan minimum isi laporan keuangan. Laporan keuangan disusun dengan menerapkan basis kas untuk pengakuan pos pos pendapatan, belanja, dan pembiayaan, serta basis akrual untuk pengakuan pos-pos aset, kewajiban, dan ekuitas. Pengakuan, pengukuran, dan pengungkapan transaksi-transaksi spesifik dan peristiwa-1 peristiwa yang lain, diatur dalam Standar Akuntansi Pemerintah lainnya.

Standar ini harus diterapkan dalam penyajian seluruh laporan keuangan untuk tujuan umum yang disusun dan disajikan dengan basis kas untuk pengakuan pos-pos pendapatan, belanja, dan pembiayaan, serta basis akrual untuk pengakuan pos-pos aset, kewajiban, dan ekuitas sesuai dengan Standar Akuntansi Pemerintah.

Laporan keuangan umum adalah laporan yang dimaksudkan untuk memenuhi kebutuhan pengguna. Yang dimaksud dengan pengguna adalah masyarakat, Dewan Perwakilan Rakyat (DPR)/Dewan Perwakilan Rakyat Daerah (DPRD), investor/kreditor, 
manajemen pemerintah, dan lembaga internasional. Laporan keuangan meliputi laporan keuangan yang disajikan terpisah atau bagian dari laporan keuangan yang disajikan dalam dokumen publik lainnya seperti laporan tahunan. Standar ini diterapkan untuk entitas pemerintah secara keseluruhan dalam menyusun laporan keuangan suatu entitas pemerintah pusat, pemerintah daerah, dan laporan keuangan konsolidasian. Laporan keuangan konsolidasian dimaksudkan untuk menyajikan statistik keuangan pemerintah. Entitas pemerintah diperkenankan untuk menyelenggarakan akuntansi dan menyajikan laporan keuangan dengan menggunakan basis akrual, baik dalam pengakuan pendapatan, belanja, dan pembiayaan, maupun dalam pengakuan aset, kewajiban, dan ekuitas.

\section{Definisi dan karakteristik akun dalam Standar Akuntansi Pemerintahan}

Istilah-istilah berikut ini digunakan dalam standar dengan pengertian berikut:

> Arus Kas adalah arus masuk dan keluar kas dan setara kas.

$>$ Aset adalah sumber daya ekonomi yang dikuasai dan/atau dimiliki oleh pemerintah sebagai akibat dari peristiwa masa lalu dan dari mana manfaat ekonomi/sosial di masa depan diharapkan dapat diperoleh, baik oleh pemerintah maupun masyarakat, serta dapat diukur dalam satuan uang, termasuk sumber daya nonkeuangan yang diperlukan untuk penyediaan jasa bagi masyarakat umum dan untuk pemeliharaan sumber sumber daya karena alasan sejarah dan budaya.

> Aset tak berwujud adalah aset nonkeuangan yang dapat diidentifikasi dan tidak mempunyai wujud fisik serta dimiliki untuk digunakan dalam menghasilkan barang atau jasa atau digunakan untuk tujuan lainnya termasuk hak atas kekayaan intelektual.

> Belanja adalah semua pengeluaran kas umum negara/kas daerah yang mengurangi ekuitas dana lancar dalam periode tahun anggaran bersangkutan yang tidak akan diperoleh kembali pembayarannya oleh pemerintah.

$>$ Basis akrual adalah basis akuntansi yang mengakui pengaruh transaksi dan peristiwa lainnya pada saat transaksi dan peristiwa itu terjadi, tanpa memperhatikan saat kas atau setara kas diterima atau dibayarkan.

$>$ Basis kas adalah basis akuntansi yang mengakui pengaruh transaksi dan peristiwa lainnya pada saat kas atau setara kas diterima atau dibayar.

$>$ Ekuitas Dana adalah kekayaan bersih pemerintah yang merupakan selisih antara aset dan kewajiban pemerintah.

$>$ Entitas ekonomi adalah suatu kelompok entitas yang terdiri dari satu entitas pengendali dan satu atau lebih entitas kendalian.

$>$ Entitas kendalian adalah suatu entitas yang berada di bawah kendali entitas lainnya. Entitas yang mengendalikan entitas lainnya dikenal sebagai entitas pengendali. 
$>$ Entitas pengendali adalah suatu entitas yang mempunyai satu atau lebih entitas kendalian.

$>$ Kas adalah alat pembayaran yang sah yang setiap saat dapat digunakan untuk membiayai kegiatan pemerintah.

$>$ Kebijakan akuntansi adalah prinsip-prinsip, dasar-dasar, konvensi-konvensi, aturanaturan, dan praktik-praktik spesifik yang dipilih oleh suatu entitas dalam penyusunan dan penyajian laporan keuangan.

$>$ Kendali adalah kekuatan untuk mengendalikan kebijakan keuangan dan operasi entitas lainnya.

> Kewajiban adalah utang masa kini dari suatu entitas yang timbul dari peristiwa masa lalu yang penyelesaiannya akan menimbulkan arus keluar sumber-sumber yang dimiliki suatu entitas.

> Laporan keuangan konsolidasian adalah laporan 1 poran keuangan suatu entitas ekonomi yang disajikan seolah-olah seperti entitas tunggal.

$>$ Laporan keuangan interim adalah laporan keuangan yang diterbitkan di antara dua laporan keuangan tahunan. Mata uang asing adalah mata uang selain mata uang pelaporan suatu entitas.

$>$ Mata uang pelaporan adalah mata uang yang digunakan dalam menyajikan laporan keuangan.

> Materialitas. Informasi dikatakan material jika tidak tersajikannya atau salah saji akan mempengaruhi keputusan atau penilaian pengguna tersebut yang dibuat atas dasar laporan keuangan.

> Materialitas tergantung pada hakikat atau besarnya pos atau kesalahan yang dipertimbangkan dari keadaan khusus di mana kekurangan atau salah saji terjadi.

> Nilai wajar adalah nilai tukar aset atau penyelesaian kewajiban antar pihak yang memahami dan berkeinginan melakukan transaksi wajar.

> Pembiayaan (financing) adalah seluruh transaksi keuangan pemerintah, baik penerimaan maupun pengeluaran, yang perlu dibayar atau akan diterima kembali, yang dalam penganggaran pemerintah terutama dimaksudkan untuk menutup defisit dan atau memanfaatkan surplus anggaran. Penerimaan pembiayaan dapat berasal dari pinjaman dan hasil divestasi. Pengeluaran pembiayaan antara lain digunakan untuk pembayaran kembali pokok pinjaman, pemberian pinjaman kepada 1 pada entitas lain, dan penyertaan modal oleh pemerintah.

> Pendapatan adalah semua penerimaan kas umum negara/kasdaerah yang menambah ekuitas dana dalam periode tahun anggaran bersangkutan yang menjadi hak pemerintahnpusat/daerah, yang tidak perlu dibayar kembali oleh pemerintah pusat/daerah. 
> Persediaan adalah barang habis pakai yang diperoleh dengan maksud untuk mendukung operasional pemerintah.

$>$ Piutang transfer adalah hak suatu entitas untuk menerima pembayaran dari entitas lain sebagai akibat ketentuan perundang undangan.

$>$ Selisih kurs adalah selisih yang timbul karena penjabaran valuta asing pada kurs yang berbeda.

> Setara kas adalah investasi jangka pendek dan sangat likuid yang siap dikonversikan menjadi kas dengan jumlah tertentu serta bebas dari perubahan nilai signifikan.

$>$ Surplus/defisit adalah selisih lebih/kurang antara pendapatan dan belanja selama satu periode pelaporan.

> Tanggal pelaporan adalah tanggal hari terakhir dari suatu periode pelaporan.

> Transfer adalah penerimaan/pengeluaran uang dari suatu entitas kepada entitas lain, termasuk dana perimbangan dan dana bagi hasil.

> Utang transfer adalah kewajiban suatu entitas untuk melakukan pembayaran kepada entitas lain sebagai akibat ketentuan perundang-undangan.

\section{Komponen komponen Laporan Keuangan}

Komponen-komponen yang terdapat dalam suatu set laporan keuangan pokok adalah:

(a) Laporan Realisasi Anggaran

(b) Neraca

(c) Laporan Arus Kas

(d) Catatan atas Laporan Keuangan

Komponen-komponen laporan keuangan tersebut disajikan oleh setiap entitas pelaporan, kecuali laporan arus kas yang disajikan oleh unit yang memegang fungsi perbendaharaan. Komponen-komponen tersebut pada paragraf 14 dikenal juga dengan berbagai istilah di antara pemerintah pusat dan daerah. Laporan Realisasi Anggaran dikenal juga dengan istilah Laporan Perhitungan Anggaran. Laporan Arus Kas dikenal juga dengan istilah Laporan Aliran Kas. Sedangkan Nota Perhitungan Anggaran merupakan bagian dari Catatan atas Laporan Keuangan. Laporan keuangan memberikan informasi tentang sumber daya dan kewajiban entitas pada tanggal pelaporan dan arus sumber daya selama periode berjalan. Informasi ini diperlukan satu pengguna untuk melakukan penilaian terhadap kemampuan entitas dalam menyelenggarakan kegiatan pemerintahan di masa mendatang. Pemerintah dibatasi dengan anggaran dalam bentuk apropriasi atau otorisasi anggaran. Laporan keuangan menyediakan informasi mengenai apakah sumber daya telah diperoleh dan digunakan sesuai dengan anggaran yang telah ditetapkan. Laporan Realisasi Anggaran memuat anggaran dan realisasi. Entitas menyajikan tambahan informasi untuk membantu 
para pengguna dalam memperkirakan kinerja entitas dan pengurusan aset, seperti halnya dalam pembuatan dan evaluasi keputusan mengenai alokasi sumber daya. Tambahan informasi ini meliputi rincian mengenai output entitas dan outcomes dalam bentuk indikator kinerja, laporan kinerja, tinjauan program dan laporan lain mengenai pencapaian kinerja entitas selama periode pelaporan. Suatu entitas diperkenankan menyajikan laporan kinerja keuangan berbasis akrual dan laporan perubahan ekuitas. Entitas mengungkapkan informasi tentang ketaatan pada peraturan perundang-undangan.

\section{Badan Layanan Umum (BLU)}

\section{Konsep dan Definisi}

\section{PP No. 23 Tahun 2005 tentang Pengelolaan Keuangan Badan Layanan Umum}

Badan Layanan Umum, yang selanjutnya disebut BLU, adalah instansi di Lingkungan Pemerintah yang dibentuk untuk memberikan pelayanan Kepada masyarakat berupa penyediaan barang dan/atau jasa yang dijual tanpa mengutamakan mencari keuntungan dan dalam melakukan kegiatannya didasarkan pada prinsip efisiensi dan produktivitas.

Pola Pengelolaan Keuangan Badan Layanan Umum (PPK-BLU) adalah pola pengelolaan keuangan yang memberikan fleksibilitas berupa keleluasaan untuk menerapkan praktek-praktek bisnis yang sehat untuk meningkatkan pelayanan kepada masyarakat dalam rangka memajukan kesejahteraan umum dan mencerdaskan kehidupan bangsa, sebagaimana diatur dalam Peraturan Pemerintah ini, sebagai pengecualian dari ketentuan pengelolaan keuangan negara pada umumnya.

\section{Tujuan}

\section{PP No. 23 Tahun 2005 tentang Pengelolaan Keuangan Badan Layanan Umum}

- BLU bertujuan untuk meningkatkan pelayanan kepada masyarakat dalam rangka memajukan kesejahteraan umum dan mencerdaskan kehidupan bangsa dengan memberikan fleksibilitas dalam pengelolaan keuangan berdasarkan prinsip ekonomi dan produktivitas, dan penerapan praktek bisnis yang sehat.

- BLU beroperasi sebagai unit kerja kementerian negara/lembaga/pemerintah daerah untuk tujuan pemberian layanan umum yang pengelolaannya berdasarkan kewenangan yang didelegasikan oleh instansi induk yang bersangkutan.

- BLU merupakan bagian perangkat pencapaian tujuan kementerian negara/lembaga/pemerintah daerah dan karenanya status hukum BLU tidak terpisah dari kementerian negara/lembaga/pemerintah daerah sebagai instansi induk. 
- Menteri/pimpinan lembara/gubernur/bupati/walikota bertanggung jawab atas pelaksanaan kebijakan penyelenggaraan pelayanan umum yang didelegasikannya kepada BLU dari segi manfaat layanan yang dihasilkan.

- Pejabat yang ditunjuk mengelola BLU bertanggung jawab atas pelaksanaan kegiatan pemberian layanan umum yang didelegasikan kepadanya oleh menteri/pimpinan lembaga/gubernur/bupati/ walikota.

- BLU menyelenggarakan kegiatannya tanpa mengutamakan pencarian keuntungan. Rencana kerja dan anggaran serta laporan keuangan dan kinerja BLU disusun dan disajikan sebagai bagian yang tidak terpisahkan dari rencana kerja dan anggaran serta laporan keuangan dan kinerja kementerian negara/lembaga/SKPD/pemerintah daerah.

\section{Bidang Layanan}

\section{PP No. 23 Tahun 2005 tentang Pengelolaan Keuangan Badan Layanan Umum}

Bidang layanan umum yang diselenggarakan oleh instansi dengan PPK-BLU meliputi kegiatan pemerintah yang bersifat operasional dalam menyelenggarakan pelayanan umum yang menghasilkan semi barang/jasa publik (quasi public goods).

Suatu satuan kerja instansi pemerintah dapat diizinkan mengelola keuangan dengan PPK-BLU apabila instansi pemerintah yang bersangkutan menyelenggarakan layanan umum yang berhubungan dengan:

a. Penyediaan barang dan/atau jasa layanan umum;

b. Pengelolaan wilayah/kawasan tertentu untuk tujuan meningkatkan perekonomian masyarakat atau layanan umum; dan/atau

c. Pengelolaan dana khusus dalam rangka meningkatkan ekonomi dan/atau pelayanan kepada masyarakat.

\section{Prosedur Penetapan BLU}

\section{PP No. 23 Tahun 2005 tentang Pengelolaan Keuangan Badan Layanan Umum}

(1) Menteri/pimpinan lembaga/kepala SKPD mengusulkan instansi pemerintah yang memenuhi persyaratan substantif, teknis, dan administratif untuk menerapkan PPK-BLU kepada Menteri Keuangan/gubernur/bupati/walikota, sesuai dengan kewenangannya.

(2) Menteri Keuangan/gubernur/bupati/walikota menetapkan instansi pemerintah yang telah memenuhi persyaratan untuk menerapkan PPK-BLU. 
(3) Penetapan dapat berupa pemberian status BLU secara penuh atau status BLU bertahap.

(4) Status BLU secara penuh diberikan apabila seluruh persyaratan sebagaimana dimaksud pada ayat (1) telah dipenuhi dengan memuaskan.

(5) Status BLU-Bertahap diberikan apabila persyaratan substantive dan teknis telah terpenuhi, namun persyaratan administrative belum terpenuhi secara memuaskan.

(6) Status BLU-Bertahap berlaku paling lama 3 (tiga) tahun.

(7) Menteri Keuangan/gubernur/bupati/walikota, sesuai dengan kewenangannya, memberi keputusan penetapan atau surat penolakan terhadap usulan penetapan BLU paling lambat 3 (tiga) bulan sejak diterima dari menteri/pimpinan lembaga/kepala SKPD.

Penerapan PPK-BLU berakhir apabila:

a. Dicabut oleh Menteri Keuangan/gubernur/bupati/walikota sesuai dengan kewenangannya;

b. Dicabut oleh Menteri Keuangan/gubernur/bupati/walikota berdasarkan usul dari menteri/pimpinan lembaga/kepala SKPD, sesuai dengan kewenangannya; atau

c. Berubah statusnya menjadi badan hukum dengan kekayaan negara yang dipisahkan.

\section{Pengelolaan Keuangan BLU}

\section{PP No. 23 Tahun 2005 tentang Pengelolaan Keuangan Badan Layanan Umum}

1. BLU menyusun rencana strategis bisnis lima tahunan dengan mengacu kepada Rencana Strategis Kementerian Negara/Lembaga (Renstra-KL) atau Rencana Pembangunan Jangka Menengah Daerah (RPJMD).

2. BLU menyusun RBA tahunan dengan mengacu kepada rencana strategis bisnis.

3. RBA disusun berdasarkan basis kinerja dan perhitungan akuntansi biaya menurut jenis layanannya.

4. RBA BLU disusun berdasarkan kebutuhan dan kemampuan pendapatan yang diperkirakan akan diterima dari masyarakat, badan lain, dan APBN/APBD.

Dalam rangka pengelolaan kas, BLU menyelenggarakan hal-hal sebagai berikut:
a) Merencanakan penerimaan dan pengeluaran kas;
b) Melakukan pemungutan pendapatan atau tagihan;
c) Menyimpan kas dan mengelola rekening bank;
d) Melakukan pembayaran;
e) Mendapatkan sumber dana untuk menutup defisit jangka pendek; 
f) Memanfaatkan surplus kas jangka pendek untuk memperoleh pendapatan tambahan

\section{Tata Kelola}

PP No. 23 Tahun 2005 tentang Pengelolaan Keuangan Badan Layanan Umum Pejabat pengelola BLU terdiri atas:
a. Pemimpin
b. Pejabat keuangan
c. Pejabat teknis.

Pejabat pengelola BLU dan pegawai BLU dapat terdiri dari pegawai negeri sipil dan/atau tenaga profesional non-pegawai negeri sipil sesuai dengan kebutuhan BLU.

\section{Pembinaan dan Pengawasan}

\section{PP No. 23 Tahun 2005 tentang Pengelolaan Keuangan Badan Layanan Umum}

(1) Pembinaan teknis BLU dilakukan oleh menteri/pimpinan lembaga/kepala SKPD terkait.

(2) Pembinaan keuangan BLU dilakukan oleh Menteri Keuangan/PPKD sesuai dengan kewenangannya.

(3) Dalam pelaksanaan pembinaan dapat dibentuk dewan pengawas.

(4) Pembentukan dewan pengawas berlaku hanya pada BLU yang memiliki realisasi nilai omzet tahunan menurut laporan realisasi anggaran atau nilai aset menurut neraca yang memenuhi syarat minimum yang ditetapkan oleh Menteri Keuangan.

(5) Dewan pengawas BLU di lingkungan pemerintah pusat dibentuk dengan keputusan menteri/pimpinan lembaga atas persetujuan Menteri Keuangan.

(6) Dewan pengawas BLU di lingkungan pemerintah daerah dibentuk dengan keputusan gubernur/bupati/walikota atas usulan kepala SKPD.

Perihal Pemeriksaan :

(1) Pemeriksaan intern BLU dilaksanakan oleh satuan pemeriksaan intern yang merupakan unit kerja yang berkedudukan langsung di bawah pemimpin BLU.

(2) Pemeriksaan ekstern terhadap BLU dilaksanakan oleh pemeriksa ekstern sesuai dengan ketentuan peraturan perundang-undangan.

\section{Renumerasi}

\section{PP No. 23 Tahun 2005 tentang Pengelolaan Keuangan Badan Layanan Umum}

Remunerasi sebagaimana dimaksud adalah imbalan kerja yang dapat berupa gaji, tunjangan tetap, honorarium, insentif, bonus atas prestasi, pesangon, dan/atau pensiun. 
Penetapan remunerasi dalam peraturan dimaksud harus mempertimbangkan prinsip proporsionalitas, kesetaraan, dan kepatutan.

(1) Pejabat pengelola, dewan pengawas, dan pegawai BLU dapat diberikan remunerasi berdasarkan tingkat tanggung jawab dan tuntutan profesionalisme yang diperlukan.

(2) Remunerasi ditetapkan berdasarkan Peraturan Menteri Keuangan/gubernur/bupati/walikota atas usulan menteri/pimpinan lembaga/kepala SKPD, sesuai dengan kewenangannya.

\section{METODOLOGI PENELITIAN}

\section{Analisis Deskriptif}

Analisis deskriptif adalah suatu metode yang mempelajari cara penyajian suatu gambaran atau informasi inti dari sekumpulan data yang ada, misalnya pemusatan data dan kecenderungan suatu gugus data. Untuk melakukan analisis deskriptif dari suatu data dapat dilakukan melalui 3 (tiga) tahapan:

a. Menyusun data yang tersedia (raw data) dalam bentuk tabulasi data dengan beberapa cara sesuai keperluan, antara lain:

b. Dari hasil penyusunan data dalam bentuk tabulasi data kemudian dihitung nilai-nilai yang menggambarkan segi-segi yang sangat penting dari data tersebut seperti pemusatan data atau penjabaran data.

c. Berdasarkan nilai-nilai yang telah dihitung selanjutnya dapat diambil suatu kesimpulan yaitu dengan diketahuinya gambaran atau informasi secara umum dari suatu gugus data.

\section{Analisis Program}

Analisis ini ditujukan untuk mengetahui dampak dari porgram yang telah dilaksanakan dan melakukan evaluasi terhadap perbaikan program di masa selanjutnya. Dalam analisis ini tentunya akan menggali informasi yang bersifat kualitatif dengan standarisasi yang telah ditentukan.

\section{PEMBAHASAN}

\section{Laporan Realisasi Anggaran}

Laporan realisasi anggaran menyajikan ikhtisar sumber, alokasi dan pemakaian sumber daya yang dikelola oleh pemerintah pusat/daerah dalam satu periode pelaporan. Laporan realisasi anggaran harus menyajikan pos-pos sebagai berikut:

- Pendapatan 
- Belanja

- Transfer

- Dana Cadangan

- Surplus/Defisit

- Pembiayaan.

Laporan realisasi anggaran menggambarkan perbandingan antara anggaran pendapatan, belanja dan pembiayaan dengan realisasinya dalam satu periode pelaporan.

Laporan realisasi anggaran harus disertai informasi tambahan yang menyelaraskan hal-hal yang mempengaruhi pelaksanaan anggaran seperti kebijakan fiskal dan moneter, sebab-sebab terjadinya perbedaan yang material antara anggaran dan realisasinya serta daftar-daftar yang merinci lebih lanjut angka-angka yang dianggap perlu untuk dijelaskan.

\section{Format Laporan Neraca}

\section{Aset Lancar}

Suatu aset harus diklasifikasikan sebagai aset lancar jika:

- diharapkan untuk direalisasikan dalam, atau dimiliki untuk dijual atau dipakai dalam waktu 12 (dua belas bulan) sejak tanggal pelaporan, dimiliki khususnya untuk dijual atau diharapkan segera untuk direalisasikan dalam waktu 12 (dua belas bulan) dari tanggal pelaporan, atau kas dan aset setara kas.

- Semua aset lainnya harus diklasifikasikan sebagai aset nonlancar. Aset lancar meliputi kas dan setara kas, piutang, dan persediaan. Pos-pos piutang meliputi antara lain piutang pajak, retribusi, denda, penjualan angsuran, tuntutan ganti rugi, dan piutang lainnya yang diharapkan diterima dalam waktu dua belas bulan setelah tanggal pelaporan.

\section{Aset Non Lancar}

Aset nonlancar diklasifikasikan menjadi investasi permanen, aset tetap, dan aset lainnya untuk mempermudah pemahaman atas pos-pos asset nonlancar yang disajikan di neraca.

Investasi permanen adalah investasi jangka panjang yang diadakan dengan maksud untuk mendapatkan manfaat ekonomi dalam jangka waktu lebih dari dua belas bulan. Investasi permanen terdiri dari:

- Penyertaan modal dalam badan usaha milik negara/daerah, lembaga keuangan negara, badan hukum milik negara, badan internasional dan badan hukum lainnya bukan milik negara; 
- Pinjaman kepada badan usaha milik negara/daerah, lembaga keuangan negara, pemerintah pusat/daerah, dan pihak lainnya termasuk pinjaman luar negeri yang diteruspinjamkan;

- Penanaman modal dalam proyek pembangunan yang dapat dialihkan kepada fihak ketiga; dan

- Investasi permanen lain yang dimiliki dengan maksud untuk menghasilkan pendapatan.

Aset tetap adalah aset berwujud yang mempunyai masa manfaat lebih dari dua belas bulan untuk digunakan dalam kegiatan pemerintah atau dimanfaatkan oleh masyarakat umum. Aset tetap terdiri dari:

- Tanah;

- Peralatan dan mesin;

- Gedung dan bangunan;

- Jalan, irigasi dan jaringan;

- Aset tetap lainnya; dan

- Konstruksi dalam pengerjaan.

Aset nonlancar lainnya diklasifikasikan sebagai aset lainnya. Termasuk dalam aset lainnya adalah dana cadangan dan aset tak berwujud.

\section{Kewajiban Jangka Pendek}

Suatu kewajiban harus diklasifikasikan sebagai kewajiban jangka pendek jika diharapkan untuk dibayar dalam waktu dua belas bulan setelah tanggal pelaporan. Semua kewajiban lainnya harus diklasifikasikan sebagai kewajiban jangka panjang..

Kewajiban jangka pendek dapat dikategorikan dengan cara yang sama seperti aset lancar. Beberapa kewajiban jangka pendek, seperti utang transfer pemerintah atau utang kepada pegawai merupakan suatu bagian yang akan menyerap aset lancar dalam tahun pelaporan berikutnya.

Kewajiban jangka pendek lainnya adalah kewajiban yang jatuh tempo dalam waktu dua belas bulan setelah tanggal pelaporan. Misalnya bunga pinjaman, utang jangka pendek dari pihak ketiga, utang perhitungan fihak ketiga (PFK), dan bagian lancar utang jangka panjang.

\section{Kewajiban Jangka Panjang}

Suatu entitas harus tetap mengklasifikasikan kewajiban jangka panjangnya, meskipun kewajiban tersebut jatuh tempo dan untuk diselesaikan dalam waktu dua belas bulan setelah tanggal pelaporan jika: 
- jangka waktu aslinya adalah untuk periode lebih dari dua belas bulan;

- entitas bermaksud untuk mendanai kembali (refinance) kewajiban tersebut atas dasar jangka panjang;

Maksud tersebut didukung dengan adanya suatu perjanjian pendanaan kembali (refinancing), atau adanya penjadualan kembali terhadap pembayaran, yang diselesaikan sebelum laporan keuangan disetujui. Jumlah setiap kewajiban yang dikeluarkan dari kewajiban jangka pendek sesuai dengan paragraf ini, bersama-sama dengan informasi yang mendukung penyajian ini, harus diungkapkan dalam catatan atas laporan keuangan.

Beberapa kewajiban yang jatuh tempo untuk dilunasi pada tahun berikutnya mungkin diharapkan untuk dapat didanai kembali (refinancing) atau digulirkan (roll over) berdasarkan kebijakan entitas dan diharapkan tidak akan segera menyerap dana entitas. Kewajiban yang demikian dipertimbangkan untuk menjadi suatu bagian dari pembiayaan jangka panjang dan harus diklasifikasikan sebagai kewajiban jangka panjang. Namun dalam situasi di mana kebijakan pendanaan kembali tidak berada pada entitas (seperti dalam kasus tidak adanya persetujuan pendanaan kembali), pendanaan kembali ini tidak dapat dipertimbangkan secara otomatis dan kewajiban ini diklasifikasikan sebagai pos jangka pnedek kecuali penyelesaian atas perjanjian pendanaan kembali sebelum persetujuan laporan keuangan membuktikan bahwa substansi kewajiban pada tanggal pelaporan adalah jangka panjang.

Beberapa perjanjian pinjaman menyertakan persyaratan tertentu (covenant) yang menyebabkan kewajiban jangka panjang menjadi kewajiban jangka pendek (payable on demand) jika persyaratan tertentu yang terkait dengan posisi keuangan peminjam dilanggar. Dalam keadaan demikian, kewajiban dapat diklasifikasikan sebagai kewajiban jangka panjang hanya jika:

- pemberi pinjaman telah menyetujui untuk tidak meminta pelunasan sebagai konsekuensi adanya pelanggaran, dan

- tidak mungkin terjadi pelanggaran berikutnya dalam waktu dua belas bulan setelah tanggal pelaporan.

\section{Informasi yang Harus Disajikan di Neraca}

Neraca harus mencantumkan sekurang-kurangnya pos-pos berikut:

- kas dan setara kas;

- piutang pajak dan bukan pajak yang timbul dari peraturan perundang-undangan;

- $\quad$ piutang dari penjualan;

- persediaan;

- investasi permanen;

- tanah, peralatan dan mesin, gedung dan bangunan, 1 jalan, 
- irigasi dan jaringan;

- kewajiban jangka pendek;

- utang transfer;

- kewajiban jangka panjang;

- ekuitas dana.

Pos-pos selain yang disebutkan pada paragraf 56 harus disajikan dalam neraca jika Standar Akuntansi Pemerintah mensyaratkan, atau jika penyajian demikian perlu untuk menyajikan secara wajar posisi keuangan suatu entitas. Contoh format neraca disajikan dalam lampiran ini. Lampiran hanya merupakan ilustrasi. Tujuan lampiran ini adalah mengilustrasikan penerapan standar untuk membantu dalam klarifikasi artinya.

Pertimbangan apakah pos-pos tambahan disajikan secara terpisah didasarkan pada penilaian dari:

- Sifat, likuiditas, dan materialitas aset;

- Fungsi pos-pos tersebut dalam entitas;

- Jumlah, sifat, dan jangka waktu kewajiban.

Aset dan kewajiban yang berbeda dalam sifat dan fungsi kadang-kadang diukur dengan dasar pengukuran yang berbeda. Sebagai contoh, asset tertentu dicatat atas dasar biaya perolehan atau penilaian kembali, oleh karena itu dasar pengukuran yang berbeda untuk setiap asset mengindikasikan bahwa sifat dan fungsi aset tersebut juga berbeda sehingga aset tersebut harus disajikan secara terpisah.

\section{Format Laporan Arus Kas}

Laporan arus kas adalah laporan untuk memberi informasi mengenai arus masuk dan keluar kas dan setara kas dari suatu entitas pemerintah selama satu periode pelaporan.

Arus masuk dan keluar kas diklasifikasikan berdasarkan aktivitas operasi, investasi, pembiayaan, dan non-anggaran, menyatakan persyaratan-persyaratan untuk penyajian laporan arus kas dan pengungkapan yang berhubungan dengan arus kas. Standar tersebut menyatakan bahwa informasi arus kas bermanfaat bagi pengguna laporan keuangan dengan menyediakan dasar dalam penaksiran kemampuan entitas untuk menghasilkan kas dan setara kas, serta kebutuhan entitas dalam penggunaan arus kas tersebut

\section{Format Catatan Atas Laporan Keuangan}

\section{Struktur}

Keuangan adalah penyajian informasi yang diharuskan dan dianjurkan oleh Standar Akuntansi Pemerintah serta pengungkapan pengungkapan lainnya yang diperlukan untuk 
penyajian yang wajar atas laporan keuangan, seperti kewajiban kontinjensi dan komitmenkomitmen lainnya.

Agar dapat digunakan oleh pengguna dalam memahami dan membandingkannya dengan laporan keuangan entitas lainnya, Catatan atas Laporan Keuangan biasanya disajikan dengan susunan sebagai berikut:

- informasi tentang kebijakan fiskal/keuangan, ekonomi makro, pencapaian target Undang-undang APBN/Perda APBD, berikut kendala dan hambatan yang dihadapi dalam pencapaian target

- informasi tentang ikhtisar pencapaian kinerja selama tahun pelaporan

- pernyataan tentang ketaatan terhadap Standar Akuntansi Pemerintah

- pernyataan tentang dasar pengukuran dan kebijakan akuntansi yang diterapkan

- informasi yang menjelaskan pos-pos laporan keuangan sesuai dengan urutan sebagaimana pos-pos tersebut disajikan dalam lembar muka laporan keuangan;

- informasi lainnya, termasuk informasi nonkeuangan.

Dalam keadaan tertentu masih dimungkinkan untuk mengubah susunan penyajian atas pos-pos tertentu dalam Catatan atas Laporan Keuangan. Misalnya informasi tingkat bunga dan penyesuaian nilai wajar dapat digabungkan dengan informasi jatuh tempo suratsurat berharga.

\section{Penyajian Kebijakan - Kebijakan Akuntansi}

Bagian kebijakan akuntansi pada Catatan atas Laporan Keuangan harus menjelaskan hal-hal berikut ini:

- Basis pengukuran yang digunakan dalam penyusunan laporan keuangan sampai sejauh mana kebijakan-kebijakan akuntansi yang berkaitan dengan ketentuanketentuan masa transisi Standar Akuntansi Pemerintah diterapkan oleh suatu entitas

- Setiap kebijakan akuntansi tertentu yang diperlukan untuk memahami laporan keuangan.

- Pengguna laporan keuangan perlu mengetahui basis-basis pengukuran yang digunakan sebagai landasan dalam penyajian laporan keuangan. Apabila lebih dari satu basis pengukuran digunakan dalam penyusunan laporan keuangan, maka informasi yang disajikan cukup memadai untuk dapat mengindikasikan aset dan kewajiban yang menggunakan basis pengukuran tersebut.

Dalam menentukan apakah suatu kebijakan akuntansi perlu diungkapkan, manajemen harus mempertimbangkan apakah pengungkapan tersebut dapat membantu pengguna untuk memahami setiap transaksi yang tercermin dalam laporan keuangan. 
Kebijakan kebijakan akuntansi yang perlu dipertimbangkan untuk disajikan meliputi, tetapi tidak terbatas pada, hal-hal sebagai berikut:

- Pengakuan pendapatan

- Prinsip-prinsip penyusunan laporan konsolidasian

- Penyertaan-penyertaan

- Pengakuan dan penghentian/penghapusan aset berwujud dan Tidak berwujud

- Kontrak-kontrak konstruksi

- Kebijakan kapitalisasi pengeluaran

- Investasi dalam surat-surat berharga

- Kemitraan dengan pihak ketiga

- Biaya penelitian dan pengembangan

- Persediaan, baik yang untuk dijual maupun untuk dipakai sendiri

- Pembentukan dana cadangan

- Pembentukan dana kesejahteraan pegawai

- Penjabaran mata uang asing dan lindung nilai.

Setiap entitas perlu mempertimbangkan sifat kegiatan-kegiatan dan kebijakankebijakan yang perlu diungkapkan dalam catatan atas laporan keuangan. Sebagai contoh, pengungkapan informasi untuk pengakuan pajak, retribusi dan bentuk-bentuk lainya dari iuran wajib (nonreciprocal revenue), penjabaran mata uang asing, dan perlakuan akuntansi terhadap selisih kurs.

Kebijakan akuntansi bisa saja menjadi signifikan walaupun nilai pos-pos yang disajikan dalam periode berjalan dan sebelumnya tidak material. Selain itu perlu pula diungkapkan kebijakan akuntansi yang dipilih dan diterapkan yang tidak diatur dalam Standar Akuntansi Pemerintah ini.

\section{Pengungkapan pengungkapan Lainnya}

Suatu entitas harus mengungkapkan hal-hal berikut ini apabila belum diinformasikan dalam bagian mana pun dari laporan keuangan, yaitu:

- domisili dan bentuk hukum suatu entitas serta jurisdiksi dimana entitas tersebut beroperasi;

- penjelasan mengenai sifat operasi entitas dan kegiatan pokoknya;

- ketentuan perundang-undangan yang menjadi landasan kegiatan operasionalnya.

\section{Tanggal Efektif}


Standar Akuntansi Pemerintah berlaku efektif untuk laporan keuangan yang mencakupi periode mulai tanggal 1 Januari 2004. Penerapan lebih dini sangat dianjurkan.

\section{Persyaratan Masa Transisi}

Semua ketentuan dalam Standar Akuntansi Pemerintah berlaku sejak tanggal efektif. Suatu entitas harus menerapkan seluruh ketentuan dalam standar ini selambat-lambatnya 31 Desember 2004.

Laporan keuangan konsolidasian belum diwajibkan sampai dikeluarkannya standar akuntansi pemerintah yang mengatur tentang hal tersebut. 
Tabel Format Laporan NERACA

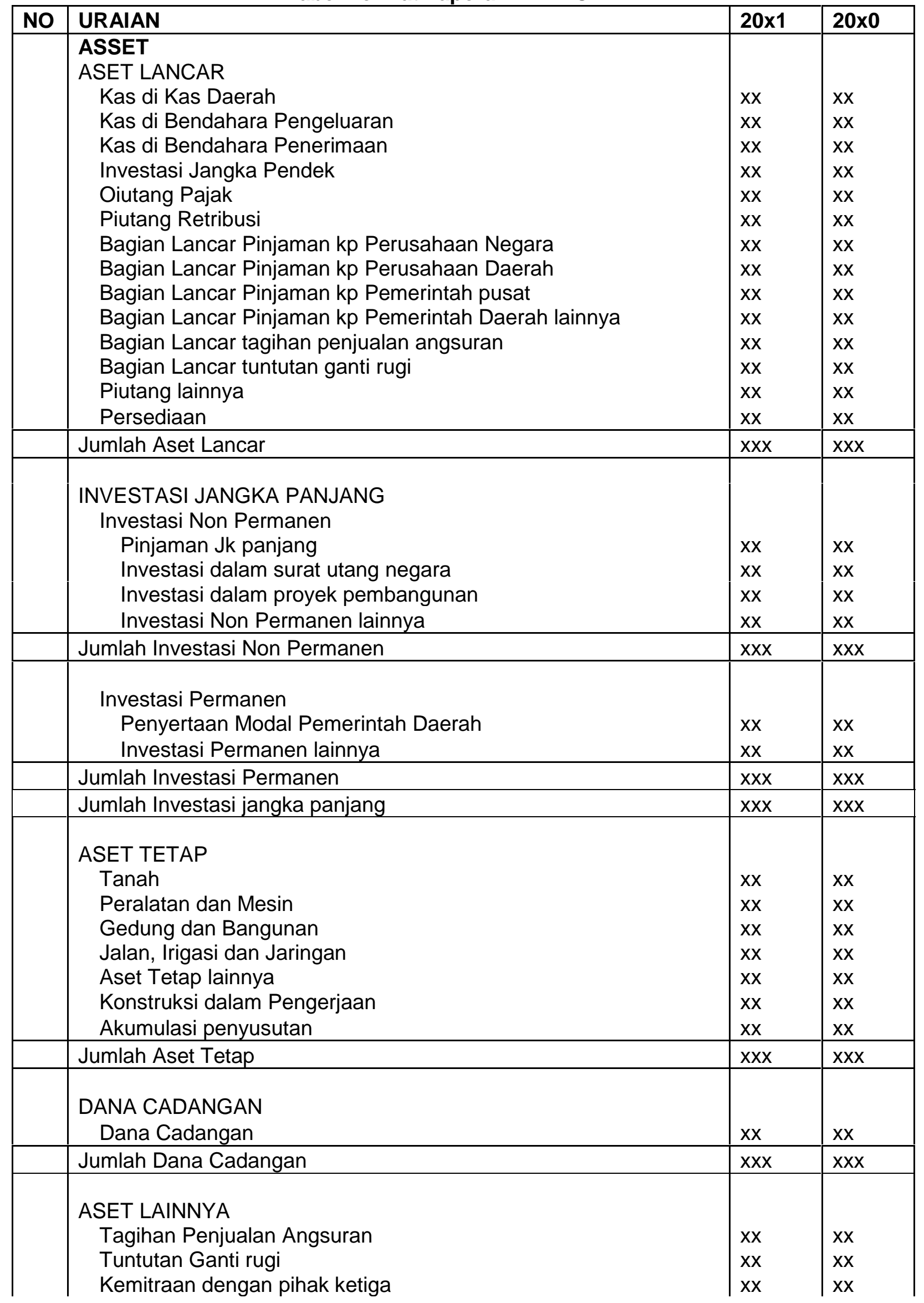




\begin{tabular}{|c|c|c|}
\hline $\begin{array}{l}\text { Aset Tak Berwujud } \\
\text { Aset Lainnya }\end{array}$ & $\begin{array}{l}x x \\
x x\end{array}$ & $\begin{array}{l}\mathrm{XX} \\
\mathrm{XX} \\
\end{array}$ \\
\hline Jumlah Aset Lainnya & $\mathrm{xxX}$ & $\mathrm{xxx}$ \\
\hline Jumlah ASET & $\mathbf{X X X}$ & $\mathbf{x x x}$ \\
\hline $\begin{array}{l}\text { KEWAJIBAN } \\
\text { KEWAJIBAN JANGKA PENDEK } \\
\text { Utang perhitungan pihak ketiga } \\
\text { Utang Bunga } \\
\text { Bagian Lancar Utang Jangka Panjang } \\
\text { Utang Jangka Pendek lainnya } \\
\end{array}$ & $\begin{array}{l}x x \\
x x \\
x x \\
x x\end{array}$ & $\begin{array}{l}x x \\
x x \\
x x \\
x x\end{array}$ \\
\hline Jumlah Kewajiban Jangka Pendek & $\mathrm{xxx}$ & $\mathrm{xxx}$ \\
\hline $\begin{array}{l}\text { KEWAJIBAN JANGKA PANJANG } \\
\text { Utang Dalam Negeri-Sektor Perbankan } \\
\text { Utang Dalam Negeri-Obligasi } \\
\text { Utang Jangka Panjang Lainnya }\end{array}$ & $\begin{array}{l}x X \\
x X \\
x X\end{array}$ & $\begin{array}{l}x x \\
x x \\
x x\end{array}$ \\
\hline Jumlah Kewajiban Jangka Panjang & $\mathrm{xxx}$ & $\mathrm{xxx}$ \\
\hline $\begin{array}{l}\text { EKUITAS DANA } \\
\text { EKUITAS DANA LANCAR } \\
\text { Silpa Sisa Lebih pembiayaan dana anggaran } \\
\text { Pendapatan yang ditangguhkan } \\
\text { Cadangan Piutang } \\
\text { Cadangan Persediaan } \\
\text { Dana yang harus disediakan utk pembayaran Utang jk Pendek }\end{array}$ & $\begin{array}{l}x X \\
x x \\
x x \\
x x \\
x x\end{array}$ & $\begin{array}{l}x x \\
x x \\
x x \\
x x \\
x x\end{array}$ \\
\hline Jumlah Ekuitas Dana Investasi & $x x x$ & $x x x$ \\
\hline $\begin{array}{l}\text { EKUITAS DANA CADANGAN } \\
\text { Diinvestasikan dalam Dana Cadangan }\end{array}$ & $\mathrm{xx}$ & $\mathrm{xx}$ \\
\hline Jumlah Ekuitas Dana & $\mathrm{xxX}$ & $\mathrm{xxx}$ \\
\hline Jumlah Kewajiban dan Ekuitas Dana & $\mathbf{X X X}$ & $\mathbf{x x X}$ \\
\hline
\end{tabular}


Tabel Formal Laporan Realisasi Anggaran

\begin{tabular}{|c|c|c|c|c|c|}
\hline \multirow[t]{2}{*}{ NO } & URAIAN & $\begin{array}{l}\text { ANGGARAN } \\
20 \mathrm{X} 1\end{array}$ & $\begin{array}{l}\text { REALISASI } \\
20 \times 1\end{array}$ & (\%) & $\begin{array}{l}\text { REALISAS } \\
\text { 20X) }\end{array}$ \\
\hline & $\begin{array}{l}\text { PENDAPATAN } \\
\text { PENDAPATAN DAERAH } \\
\text { Pendapatan Pajak } \\
\text { Pendapatan Retribusi } \\
\text { Pendapatan hasil pengelolaan daerah } \\
\text { Lain lain }\end{array}$ & $\begin{array}{l}x x \\
x x \\
x x \\
x x\end{array}$ & $\begin{array}{l}x x \\
x x \\
x x \\
x x\end{array}$ & & $\begin{array}{l}x x \\
x x \\
x x \\
x x\end{array}$ \\
\hline & Jumlah Pendapatan Asli Daerah & $x x x$ & $x x x$ & & $\mathrm{xxx}$ \\
\hline & $\begin{array}{l}\text { PENDAPATAN TRANSFER } \\
\text { TRANSFER PEMERINTAH PUSAT-DANA } \\
\text { PEMBANGUNAN } \\
\text { Dana Bagi hasil pajak } \\
\text { Dana Bagi hasil sumber daya alam } \\
\text { Dana Alokasi Umum } \\
\text { Dana Alokasi Khusus }\end{array}$ & $\begin{array}{l}x x \\
x x \\
x x \\
x x\end{array}$ & $\begin{array}{l}x x \\
x x \\
x x \\
x x \\
\end{array}$ & & $\begin{array}{l}x x \\
x x \\
x x \\
x x\end{array}$ \\
\hline & Jumlah Pendapatan Transfer Daerah & $x x x$ & $x x x$ & & $x x x$ \\
\hline & $\begin{array}{l}\text { TRANSFER PEMERINTAH PUSAT-LAINNYA } \\
\text { Dana Otonomi Khusus } \\
\text { Dana Penyesuaian }\end{array}$ & $\begin{array}{l}x x \\
x x\end{array}$ & $\begin{array}{l}x x \\
x x\end{array}$ & & $\begin{array}{l}x x \\
x x\end{array}$ \\
\hline & Jumlah Pendapatan transfer Pemerintah Pusat & $x x x$ & $x x x$ & & $x x x$ \\
\hline & Jumlah Total Pendapatan Transfer & $x \mathrm{xx}$ & $x x x$ & & $x x x$ \\
\hline & $\begin{array}{l}\text { LAIN LAIN PENDAPATAN YANG SAH } \\
\text { Pendapatan Hibah } \\
\text { Pendapatan Dana Darurat } \\
\text { Pendapatan lainnya }\end{array}$ & $\begin{array}{l}x \mathrm{x} \\
\mathrm{xx} \\
\mathrm{xx}\end{array}$ & $\begin{array}{l}x x \\
x x \\
x x\end{array}$ & & $\begin{array}{l}\mathrm{xx} \\
\mathrm{xx} \\
\mathrm{xx}\end{array}$ \\
\hline & Jumlah Pendapatan yang sah & $x x x$ & $x x x$ & & $x x x$ \\
\hline & Jumlah Total Pendapatan & $x x x$ & $x x x$ & & $x x x$ \\
\hline & $\begin{array}{l}\text { BELANJA } \\
\text { BELANJA OPERASIONAL } \\
\text { Belanja Pegawai } \\
\text { Belanja Barang } \\
\text { Bunga } \\
\text { Subsidi } \\
\text { Hibah } \\
\text { Bantuan Sosial } \\
\end{array}$ & $\begin{array}{l}x x \\
x x \\
x x \\
x x \\
x x \\
x x\end{array}$ & $\begin{array}{l}x x \\
x x \\
x x \\
x x \\
x x \\
x x\end{array}$ & & $\begin{array}{l}X X \\
X x \\
X x \\
X x \\
X x \\
X x\end{array}$ \\
\hline & Jumlah Belanja Operasional & $x x x$ & $x x x$ & & $X x x$ \\
\hline & $\begin{array}{l}\text { BELANJA MODAL } \\
\text { Belanja Tanah } \\
\text { Belanja Peralatan } \\
\text { Belanja Gedung dan Bangunan } \\
\text { Belanja Jalan Irigasi dan Jaringan }\end{array}$ & $\begin{array}{l}x x \\
x x \\
x x \\
x x\end{array}$ & $\begin{array}{l}x x \\
x x \\
x x \\
x x\end{array}$ & & $\begin{array}{l}X x \\
X x \\
X x \\
X x\end{array}$ \\
\hline & $\begin{array}{l}\text { Belanja Asset Tetap Lainnya } \\
\text { Belanja Asset lainnya }\end{array}$ & $\begin{array}{l}x x \\
x x\end{array}$ & $\begin{array}{l}x x \\
x x\end{array}$ & & $\begin{array}{l}x x \\
x x\end{array}$ \\
\hline & Jumlah Belanja Modal & $\mathrm{xxx}$ & $x x x$ & & $x x x$ \\
\hline
\end{tabular}




\begin{tabular}{|c|c|c|c|}
\hline $\begin{array}{l}\text { BELANJA TAK TERDUGA } \\
\text { Belanja tak terduga }\end{array}$ & $x X$ & $x x$ & $x x$ \\
\hline Jumlah Belanja tak terduga & $x x x$ & $x x x$ & $x x x$ \\
\hline $\begin{array}{l}\text { TRANSFER } \\
\text { BAGI HASIL KUMKM } \\
\text { Bagi Hasil Pajak } \\
\text { Bagi Hasil Retribusi } \\
\text { Bagi Hasil Pendapatan lainnya }\end{array}$ & $\begin{array}{l}X X \\
X X \\
X X \\
\end{array}$ & $\begin{array}{l}X X \\
X X \\
X X \\
\end{array}$ & $\begin{array}{l}x X \\
x X \\
x x\end{array}$ \\
\hline Jumlah Bagi hasil KUMKM & $\mathrm{xxx}$ & $x x x$ & $x x x$ \\
\hline Surplus/ Defisit & $x x x$ & $x x x$ & $x x x$ \\
\hline
\end{tabular}

\section{SIMPULAN}

Laporan keuangan merupakan laporan yang terstruktur mengenai posisi keuangan dan transaksitransaksi yang dilakukan oleh suatu entitas. Tujuan umum laporan keuangan adalah untuk menyajikan informasi mengenai posisi keuangan, kinerja, dan arus kas suatu entitas yang bermanfaat bagi para pengguna dalam membuat dan mengevaluasi keputusan mengenai alokasi sumber daya. Secara spesifik, tujuan pelaporan keuangan pemerintah adalah untuk menyajikan informasi yang berguna untuk pengambilan keputusan dan untuk menunjukkan akuntabilitas entitas atas sumber daya yang dipercayakan kepadanya, dengan: Menyediakan informasi mengenai sumber daya, alokasi, dan penggunaan sumber daya, Menyediakan informasi mengenai bagaimana entitas mendanai aktivitasnya dan memenuhi kebutuhan kasnya, Menyediakan informasi yang berguna dalam mengevaluasi kemampuan entitas untuk mendanai aktivitasnya dan memenuhi kewajiban serta komitmennya; dan Menyediakan informasi mengenai kondisi keuangan suatu entitas dan perubahannya.

Laporan keuangan untuk tujuan umum juga mempunyai peranan prediktif dan prospektif, menyediakan informasi yang berguna untuk memprediksi besarnya sumber daya yang dibutuhkan untuk operasi yang berkelanjutan, sumberdaya yang dihasilkan dari operasi yang berkelanjutan, serta resiko dan ketidakpastian yang terkait. Pelaporan keuangan juga menyajikan informasi bagi pengguna mengenai: Indikasi apakah sumber daya telah diperoleh dan digunakan sesuai dengan anggaran dan, Indikasi apakah sumber daya diperoleh dan digunakan sesuai dengan ketentuan, termasuk batas anggaran yang ditetapkan oleh DPR/DPRD.

Komponen-komponen yang harus dibuat setiap tiga bulan adalah laporan keuangan dengan pokok laporan sebagai berikut:Laporan Realisasi Anggaran, Neraca, Laporan Arus Kas, Catatan atas Laporan Keuangan,Untuk memenuhi tujuan-tujuan ini, laporan keuangan menyediakan informasi mengenai entitas dalam hal asset, kewajiban, ekuitas dana, pendapatan, belanja, pembiayaan dan arus kas. 


\section{DAFTAR PUSTAKA}

Anonimous Peraturan Gubernur Jawa Timur No. 86 Tahun 2008 tentang Uraian Tugas Sekretariat, Bidang, Sub Bagian dan Seksi Dinas Koperasi dan Usaha Mikro, Kecil, Menengah Provinsi Jawa Timur,Surabaya

Anonimous Peraturan Gubernur Jawa Timur No. 9 Tahun 2008 tentang Organisasi dan Tata Kerja Dinas Daerah Provinsi Jawa Timur,Surabaya

Anonimous Peraturan Gubernur Jawa Timur No. 124 Tahun 2008 tentang Unit Pelaksana Teknis Dinas Koperasi, Usaha Mikro, Kecil dan Menengah Provinsi Jawa Timur

Anonimous, Undang-Undang Republik Indonesia No.20 Tahun 2008 tentang usaha mikro, kecil dan menengah, Bab I tentang ketentuan umum, Jakarta

David, Fred R., 2009, Manajemen Strategis: Konsep, Salemba Empat, Jakarta

Feridhanusetyawan Tubagus dan Mari Pangestu (2003), "Indonesian Trade Liberalization: Estimating The Gains", Bulletin of Indonesian Economic Studies

IAI, 2004. Standar Akuntansi Pemerintahan, Ikatan Akuntan Indonesia, Jakarta

Jauch, L. R. Dan W. F. Glueck, 2001, Manajemen Strategis dan Kebijakan Perusahaan, Erlangga, Jakarta

Pierce II, J.A., and R.B. Robinson, 2000, Strategic management: formulation, implementation, and control, seventh editon, McGraw-Hill International.

Pierce, John A. \& Richard B. Robinson, 2005, Strategic Management, Binarupa Aksara, Jakarta Barat.

Röpke Jochen. 1993. "The entrepreneurial co-operative: A Schumpeterian Perspective Concerning the Stimulation of Co-operative Entrepreneurship", in IKOPIN, 1993. Seminar Proceeding on Cooperative

Entrepreneurship Education. Philipps University of Marburg - Konrad Adrenauer Stiftung - IKOPIN. Jatinangor.

Siagian, Sondang P., 1999, Manajemen Stratejik, Bumi Aksara, Jakarta.

Soetrisno, Noer (2001), "Rekonstruksi Pemahaman Koperasi, Merajut Kekuatan Ekonomi Rakyat", Instrans, Jakarta Stiglitz,

Joseph (2006), Making Globalization Work, New York: W.W. Norton \& Company.

Umar, Hussein, 2005, Strategic Management in Action, PT. Gramedia Pustaka Utama, Jakarta

Wheelen, Thomas L. \& J. David Hunger, 2003, Manajemen Strategis, Penerjemah: Julianto Agung, Penerbit ANDI, Yogyakarta.

Wolf, Martin (2004), Why Globalization Works, New Haven dan London: Yale University Press.

http://blog.pelaut.biz/news/kebijakan-pemerintah-di-bidang-ekonomi-a-ilmu-ekonomi-istilah

http://www.bps.go.id 
http://handy.hagemman.com/index.php/2008/01/02/angin-segar-berhembus-buat-ukm-di-jatim http://jjfm.wordpress.com/2007/12/12/ukm-jatim-belum-maksimalkan-ungsi-internet/ 